Tér és Társadalom 23. évf. 2009/2. 25-43. p.

\title{
PARADIGMAVÁLTÁS A HATÁRON ÁTNYÚLÓ KAPCSOLATOKBAN
}

\author{
(A Paradigm Shift in Cross-border Relations)
}

\section{BARANYI BÉLA}

Kulcsszavak:

európai integráció határon átnyúló kapcsolatok euroregionális szervezetek paradigmaváltás együttmüködés határok nélkül

Az európai integráció erósödésével - benne a Schengen-folyamat kiteljesedésével-gyökeres változás, ha tetszik paradigmaváltás várható a határon átnyúló kapcsolatok jellegét, tartalmát és formáit illetỏen. A határmentiség ủj dimenziói elsösorban a kisebb, konkrét bi- és trilaterális intézményesült interregionális együttmüködések elötérbe kerülését jelentik, mindenekelött a schengeni belsó határok mentén. A nagyivü határközi szervezeti rendszerek (eurorégiók) keretében és/vagy mellett felértékelödik a kisebb léptékü határ menti együitmüködések, kistérség-kistérség, kistérség-város, város-város kapcsolatok, város- és településszövetségek - kvázi "mini-eurorégiók" -, valamint a nagy- és középvárosok "kapuvárosi" (gateway) tranzitfunkcióinak és az egyéb településközi kapcsolatolnak a szerepe. Magyarország és a belsö határok mellett elhelyezkedö szomszédai esetében a határrégiók és a határon átnyúló együttmüködések elösegithetik a határtérségek közötti összekötö (hid-) szerep erösödését, a hajdan volt integrációs kapcsolatok újjászervezödését, a Trianonban széttöredezett térszerkezeti egységek "újraegyesitését", optimális esetben pedig egy új Kárpát-medencei transznacionális makroregionális gazdasági térség létrejöttét.

\section{A határmentiség európai terïleti dimenziói}

A globalizáció, az európai integráció és regionalizáció adott körülményei között az elmúlt századvég kihívásainak Európa a nemzetközi együttmüködés és integráció különböző formáival igyekezett megfelelni. Az 1980-as és 1990-es évek fordulóján Kelet-Közép-Európában bekövetkezett politikai rendszerváltás a Kárpát-medencében is új lehetóségeket teremtett, amelyek az államhatárok merev elválasztó szerepének enyhülését és a határon átnyúló kapcsolatok kiszélesítését ígérték ebben a súlyos történelmi-politikai, gazdasági-társadalmi és etnikai problémákkal terhelt térségben. A határrégiók, a határmentiség és a határon átnyúló együttmúködések növekvő szerepét mi sem bizonyítja jobban a „bővülő Európában”, minthogy jelenleg az EU területének több mint 40\%-át a határrégiók vagy államhatárok által ilyen-olyan módon érintett térségek alkotják, a tagországok lakosságának pedig mintegy harmada él határrégiókban. Európában az átlagosnál is több az államhatárok érintkezése, az ún. határsürüsödési metszéspontok száma.

Különösen igaz ez Magyarország esetében, amelyet találóan „határ menti ország” jelzővel is szoktak illetni, miután - centrális fekvése miatt is - hét országgal szomszédos, s a hét nagyrégió mindegyike érintkezik államhatárral, területének és népes- 
ségének pedig több mint egyharmada esik a határrégiókba. Azon túl, hogy a határrégiók általában a tagországok közötti történeti, regionális, gazdasági, társadalmi, etnikai, kulturális és környezeti problémák és konfliktusok területei, Európában is meglehetösen általános sajátosság a határmentiség és a periférikus jelleg egybeesése. Régtöl fogva nyilvánvaló tény a nyugat- és a kelet-európai határrégiók közötti centrum-periféria viszony kontinentális jelenléte, ami természetesen úgy mutatkozik meg, hogy míg Nyugat-Európában a határrégiók perifériaszerepe enyhébb, fejlettségi szintje kedvezőbb, addig Kelet-Közép-Európában a hátrányos helyzet akkumulációja erös, többnyire perifériák találkoznak perifériákkal - pl. Kárpáti Régió (Illés 2002; Baranyi 2004a; 2007).

A határ menti együttmüködések kellö összefogással - és az Európai Unió támogatásával - látványos fejlődést produkálhatnak, amennyiben a fejlesztési forrásokat képesek lesznek elöteremteni, megfelelően hasznosítani és a kölcsönös előnyökkel járó fejlesztésekre fordítani. Az elkövetkező évek és évtizedek gazdasági-társadalmi eredményei fogják bizonyítani, hogy a különféle intézményesült interregionális szervezetek és szerveződések mennyire életképes formái a határon átnyúló együttmüködéseknek. Akárhogyan is alakul sorsuk, szerepükkel - a tevékenységüket érintő kritikák ellenére - a jövöben is számolni kell. Az eurorégiós együttmüködések ugyanis Európa jelenleg folyó egyesítésének a szerves részét képezik.

A határon átnyúló együttmüködések szerepe és jelentősége, az államhatárok funkcióinak újraértelmezése az elmúlt évek során nemcsak a területi tudományok müvelői körében értékelödött fel, hanem az európai regionális politika formálói számára is, különös tekintettel a jelenben zajló európai integrációs folyamatok új kihívásaira. Mára minden, a határon átnyúló kapcsolatok helyzetét, fejlesztésének lehetőségeit és esélyeit érintö kérdésnek megnőtt a jelentösége, különösen a keleti bővítés után, melynek eredményeként 2004. május 1-jétől Magyarország is az Európai Unió teljes jogú tagja. Az európai integráció kiteljesedése nyomán az államhatárok merev elválasztó szerepének enyhülése a határon átivelő kapcsolatok kiszélesítésének a lehetőségeivel kecsegtet a Kárpát-medencében, azon belül Magyarország államhatárai mentén is, ahol a határrégiók számottevő része ma is gazdaságilag-társadalmilag elmaradott, halmozottan hátrányos helyzetü, periférikus terület (Baranyi 2004a).

A részben történeti, részben pedig kedvezőtlen makro- és mikrogazdasági tényezők és hatások következményei miatt a kelet-közép-európai rendszerváltó országok - köztük Magyarország és szomszédjai - számára alapvető nemzeti érdek tehát az államhatárok merev elválasztó szerepének oldódása, a határok spiritualizálódása. Annál is inkább, mert az érintkező határrégiókban válnak leginkább nyilvánvalóvá azok az Európai Unió részéröl prioritást élvezö közösségi célkitủzések, amelyek a fejlettségbeli különbségek mérséklésére, az elmaradott régiók felzárkóztatására és fejlesztésére, valamint a kohézió és az európai integráció erősítésére irányulnak. Az Európai Unió regionális politikájának stratégiai célkitüzéseit pedig az országhatárok találkozása mentén elsősorban az intézményesült határközi struktúrák, az eurorégiók és a különböző euroregionális, interregionális szervezetek, szerveződé- 
sek valósítják meg. Egyaránt érvényesül ez a funkció Magyarországon a ma még részben szürő, részben elválasztó funkcióval rendelkező külső, akárcsak a már inkább összekapcsoló funkcióval bíró belső államhatárok esetében is (Horváth 2001; 2004; Baranyi 2002; 2004b; 2007; Balcsók et al. 2005).

$\mathrm{Az}$ interregionális határon átnyúló együttmủködések tekintetében az Európai Unió tagországai, közelebbről Magyarország határrégióinak jövőjét tekintve kitörési pontként értelmezhetőek az eurorégiók, amelyek optimális esetben sokat tehetnek $a$ periférikus helyzet felszámolásáért, a határ menti fejlettségbeli különbségek mérsékléséért, az érintett régiók integrációs törekvéseinek erösitéséért. A különféle intézményesült interregionális szervezetek és szerveződések a jövőben is életképes formái lehetnek a határon átnyúló kapcsolatoknak. Az eurorégiós együttmúködések ugyanis Európa jelenleg folyó egyesitésének egyik fontos előfeltételeit jelentik.

Az intézményesült határon átnyúló interregionális - régiók közötti - együttmüködéseknek Európában már mintegy ötvenéves hagyománya van. Nyugat-Európában az első intézményesült formák az Európai Gazdasági Közösség (1957) létrejötte után kezdtek szerveződni. Tömeges és legkoncentráltabb elterjedésük pedig a hetvenes-nyolcvanas évektól a francia, német, belga, holland, luxemburgi, dán, svájci és osztrák határvidékek térségében következett be. Kelet-Közép-Európában a határ menti együttmüködést szolgáló intézményi modellek csak az 1989/90-es politikai fordulat után jöttek létre, legszámosabb előfordulásukra mindenekelőtt a német, a lengyel, a cseh, a szlovák és a magyar határtérségekben került sor. Az 1950-es évek első kísérletei után az eurorégiók ,ősképletének”, kvázi archetípusának, a máig múködö Regio Basiliensis Egyesület tekinthető, amely formálisan 1963-ban, a németfrancia-svájci hármashatár térségében alakult meg, melynek nyomán a németfrancia és a német-holland határon több régió jött létre.

$\mathrm{Az}$ eurorégiók első klasszikus, úgymond névadó, egyszersmind a későbbi eurorégiós szervezetek számára is modellként szolgáló szervezeti formája, az Enschede-Gronau székhellyel 1965-ben a német-holland határon létrejött EUROREGIO volt. Jóllehet elözményként szomszédos tartományi járások, városok, kistelepülések vezetöi hivatalosan már 1958-ban kinyilvánították készségüket a határon átnyúló együttmúködés iránt, s kvázi megalakult az EUROREGIO, a „keresztelő" egy 1965. évi kiállitásig váratott magára - az elnevezés is először egy regionális vásár neve volt. Magát az eurégió és/vagy eurorégió kifejezést is a hollandnémet határon használták először Nyugat-Európában, $s$ aligha véletlen, hogy a belga-holland-luxemburgi-francia-német határvidékek térségében találhatók meg legnagyobb számban ezek az interregionális szervezetek.

Az eurorégiós szerveződési formában a helyi és a regionális hatóságok képviselöi, a gazdasági és a társadalmi élet szereplöi vesznek részt, s miután az önkormányzatok is számottevó mértékben képviseltetik magukat az euroregionális szervezetekben, jelentős politikai és operatív szereppel bírnak, ami eleve komoly kapcsolódási pontot biztosít számukra az európai és a nemzeti döntéselökészítő és döntéshozó szervekkel. Az eurorégiók súlyát önmagában is jelzi, hogy 1971-ben közremüködésükkel jött 
létre az Európai Határrégiók Szövetsége (AEBR), amely ma már mintegy hatvan tagszervezettel, közel másfélszáz határ menti régió képviseletében az Európa Tanács és az Európai Unió határ menti együittmüködés politikájának kialakítására is nagy befolyást gyakorol, miközben megteremtették a nemzetközi jogi kereteket, s kialakították a pénzügyi támogatási politikájukat is (Interreg, Phare CBC stb.).

Az intézményesülési folyamat fontos állomása volt a Madridban 1980. május 21 -én aláirt Területi Önkormányzatok és Közigazgatási Szervek Határmenti Együttmüködéséról szóló Európai Keretegyezmény, az ún. 106-os sz. Madridi Konvenció, melyet 1999-ig 33 ország írt alá (Magyarországon 1997-ben iktatták törvénybe). A Madridi Konvenció és a hozzá kapcsolódó jelentős dokumentumok tették lehetővé a közjogi keretek között müködő határon átnyúló együttmüködési formák kialakítását, hozzájárulva ahhoz, hogy a Konvenció modellértékủ szerződéseit mind a tagállamok, mind pedig az együttmüködő határrégiók a gyakorlatba is átültessék. A jogi szabályozás révén az intézményesült határközi struktúrák létrejötte újabb lendületet kapott, lehetỏvé téve, hogy a határon átnyúló együttmüködés intézményesült formái - ezen belül a legelterjedtebbek és a legfontosabbak az eurorégiók - nemcsak mint földrajzi keretek, hanem mint intézményépítỏ szervezetek különösképpen befolyásolják a helyi (lokális) és a regionális önkormányzati rendszereket. Ebben a megközelítésben tehát az eurorégiók „,kétarcú” jelenségek, amelyek egyrészt egy sajátos földrajzi térbeli egységet jelölnek, másfelöl pedig intézményi formaként értelmezhetök (Baranyi 2007).

A határközi intézményi struktúrák közül Nyugat-Európában és Kelet-KözépEurópában a kötött és szigorúbban szabályozott eurorégiós szervezeti forma az elterjedt, míg a skandináv és mediterrán térségekben inkább a „lazább" és nyitottabb munkaközösségi forma elöfordulása a gyakoribb. A különféle munkaközösségek, eurorégiók, euroregionális szervezetek és interregionális együttmüködések száma az Európai Unióban jelenleg már mintegy kétszáz (1. ábra).

Részben az interregionális együttmüködéseket szolgáló különbözö intézményesült határközi struktúrák, mindenekelött az eurorégiók egyre növekvő fontosságával magyarázható, hogy ma már se szeri, se száma az eurorégiók különböző szempontok szerinti megközelítésének, definíció-jellegủ értelmezésének, amelyek létrejöttében mindenekelőtt az Európai Unió állásfoglalása tekinthető mérvadónak, mely szerint az „Eurorégiók: olyan szervezett, konkrét formába öntött határon átnyúló struktúrák, amelyek magukban foglalják a helyi és a regionális szint képviselöit és ha szükséges, a gazdasági és társadalmi partnereket. Az eurorégióknak saját(os) szervezeti felépítésük van, amelynek része egy választott tanács (a legfelső szint), bizottság, számos tematikus munkacsoport és egy határon átnyúló titkárság." (European Commission 1997, 3) 


\section{1. ÁBRA}

Európa határrégiói, 2000

(Border Regions in Europe, 2000)

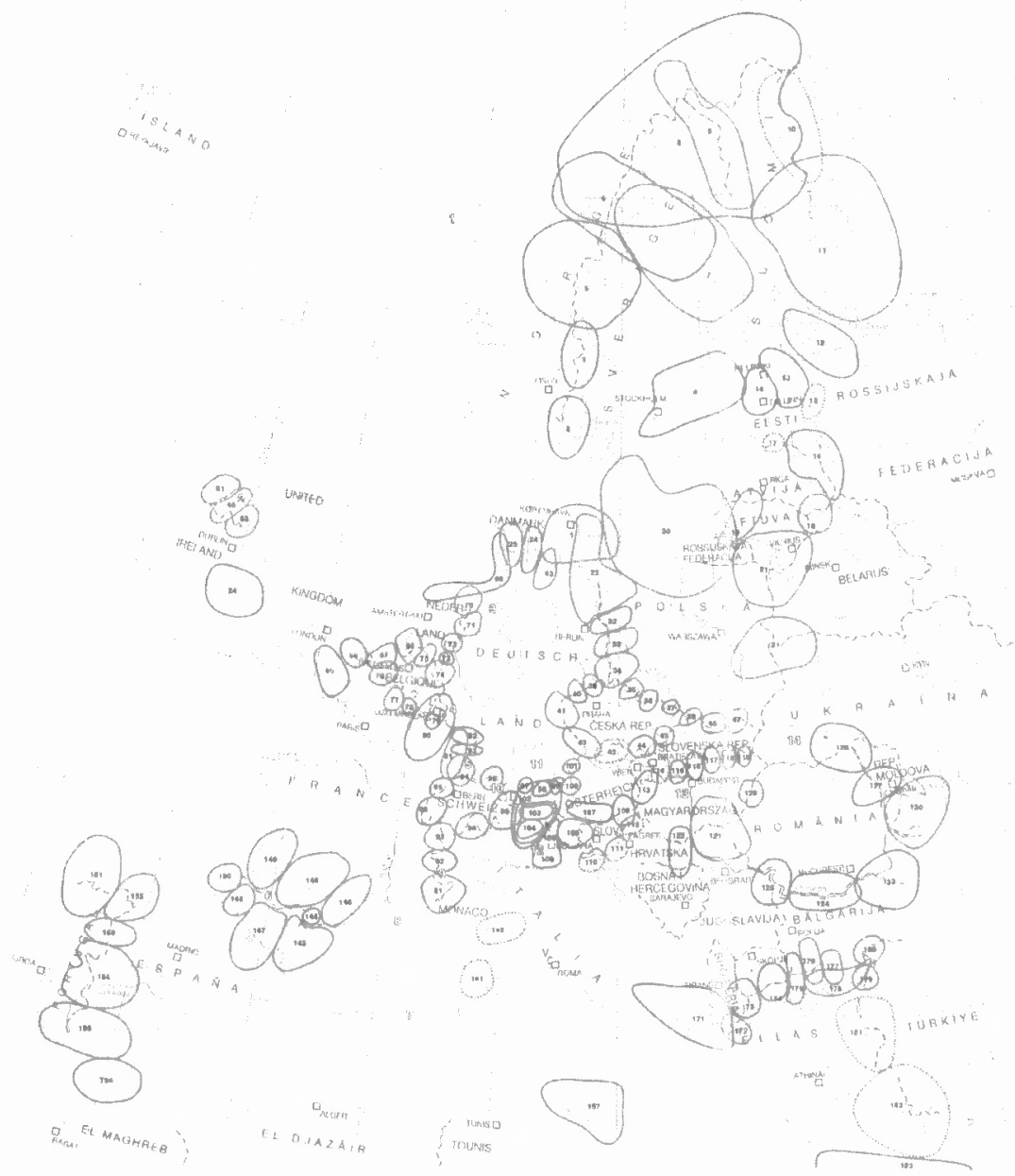

Forrás: European Comission (1997).

A rendelkezésre álló definíció-kísérletek és értelmezések sokasága alapján is könnyen megállapítható, hogy az eurorégió értelmezései ma még problematikusak, nehezen található közöttük jól megfogalmazott, pontos, széles szakmai körben közmegegyezéssel elfogadott definíció. Meglehetősen gyakori, hogy a kutatók saját definíciót alkotnak. Számos alkalommal pedig a szakirodalomban az eurorégióval kapcsolatban nem definícióra törekszenek, hanem annak jellemzóit és kritériumait sorolják fel, mint ahogy a 
leggyakrabban idézett $M$. Sucha tette, aki az alábbi hat pontban foglalta össze az eurorégiók föbb jellemzöit:

a) A határ menti együttmủködés legeredményesebb formái.

b) Segítenek leépíteni a határ menti területek fejlődésbeli különbségeit.

c) Erősítik az emberek bizalmát és együttmúködését.

d) A jószomszédság és az integráció gyakorlóterepei.

e) Segítik a múlt negatív örökségeinek meghaladását.

f) Fontos elemei a közép-európai államok betagolódásának az Európai Unióba (Sucha 1995).

A különböző definíciók értelmezésekor nem hagyható figyelmen kívül az a körülmény sem, hogy a határvidékek közötti együttmüködés intézményesített formáját megtestesítő eurorégiók Nyugat-Európában már hosszabb múltra tekintenek vissza, Kelet-Közép-Európában csak a rendszerváltások, illetve az euroatlanti folyamatok kiteljesedése nyomán jött létre a határon átívelö kapcsolatoknak ez a modellje. Az egységesülő kontinens irányítását ugyanis jelentősen megkönnyíti a legtöbbször egységes gazdasági térként funkcionáló területi egységek létrejötte, miután az eurorégiók a határon átivelö kapcsolatok sajátos földrajzi keretei. Az eurorégiók egyszersmind a legmagasabb szintü, államhatárokat áthidaló, többnyire határvidékek közötti intézményesitett együttmüködési struktúrák, a legfejlettebb és legszélesebb hatáskörü, illetve a legtöbb funkcióval rendelkező szervezetek, amelyek fó célja, hogy elismerjék öket az adott régió gazdasági, környezetvédelmi, szociális, kulturális és egyéb intézményi problémáival foglalkozó nemzetközi szerveződésként. Az ilyen tevékenységeknek eurorégiók szintjén történő koncentrálásától azt remélik, hogy olyan kritikus tömeget érhetnek el (gazdasági értelemben), amely erősíti a határ menti térségek kohézióját, illetve felkelti a magánbefektetök és intézmények érdeklődését (Scott 1997; Horváth 2000).

Az eurorégióknak a határon átnyúló együttmüködések rendszerében, illetve hierarchiájában elfoglalt helyüket tekintve, tapasztalatok alapján mindenekelőtt két területi-térségi szint, a regionális közép- vagy mezoszint, illetve a helyi vagy mikroszint említhető meg, attól függően, hogy a területi szereplők közül a középszintűek vagy inkább a helyiek dominálnak. Az eurorégiók sorában különbséget lehet tehát tenni makro- és mikroszintü eurorégiók között, ami annyit jelent, hogy vannak olyan eurorégiók, amelyeket túlnyomórészt és/vagy kizárólagosan régiók, megyék, tehát középszintü közigazgatási egységek alkotnak, és vannak olyanok, amelyekben inkább a helyi szereplók (települések, városok, kistérségek, kamarák stb.) játsszák a vezető szerepet. A területi kiterjedés és szereplők nem élesen elválasztható kategóriák, bár éppen Magyarország esetében a Kárpátok Eurorégió és a Duna-Körös-Maros-Tisza Eurorégió olyan kivételek, amelyek keretei között jöttek létre ,, mikroszintü”, ún. minieurorégiók (Interregio, Hajdú-Bihar-Bihor Eurorégió, Bihar-Bihor Eurorégió, Kassa-Miskolc Eurorégió, Zemplén Eurorégió stb.), és amelyek igazából feluulről „lógnak ki” a makrotípusból, ami egyszersmind annyit jelent, hogy a makro- (nemzetállami) szint messze nem garantálja az eurorégiók hatékony együttmüködését (Novotny 2003; Baranyi 2007). 


\section{Euroregionális és egyéb interregionális együttmüködések Magyarországon}

Magyarországnak alapvető nemzeti érdeke történelmi okokból is az 1920. évi Trianoni békeszerződés által szétszabdalt és széttöredezett, korábban viszonylag egységes gazdasági térszerkezet és vonzáskapcsolatok helyreállitása, a Kárpát-medencét véglegesen megosztó politikai államhatárok elválasztó jellegének a mérséklése, a megfelelö módon átjárható államhatárok megteremtése, a határon átívelö kapcsolatok fejlesztése (2. ábra). A folyamat kiteljesedése természetesen nem nélkülözheti a szomszédos országok együttmüködését sem, különösképp, hogy azok hivatalos politikai körei gyakorta érzékelnek még ma is veszélyt a határok két oldalán élő magyarság szorosabb együttmüködésében. Mindez pedig kedvezötlen hatást gyakorolhat a szomszédsági, s nem utolsó sorban a magyar-magyar és az interetnikus kapcsolatok alakulására. Ezért a határon átnyúló kapcsolatokban is olyan feltételek és körülmények megteremtésére kell törekedni, amelyek a lehetöségek szerinti minimumra csökkentik az anyaország határain kívül élő magyarságra nehezedö negatív hatásokat (Tóth 1996).

\section{2. ÁBRA}

Az 1920. évi Trianoni békeszerzödés következtében vonzásközpontjukat vesztett határ menti területek Magyarországon

(Border Areas in Hungary Deprived of Their Centre of Attraction by the Peace Treaty of Trianon in 1920)

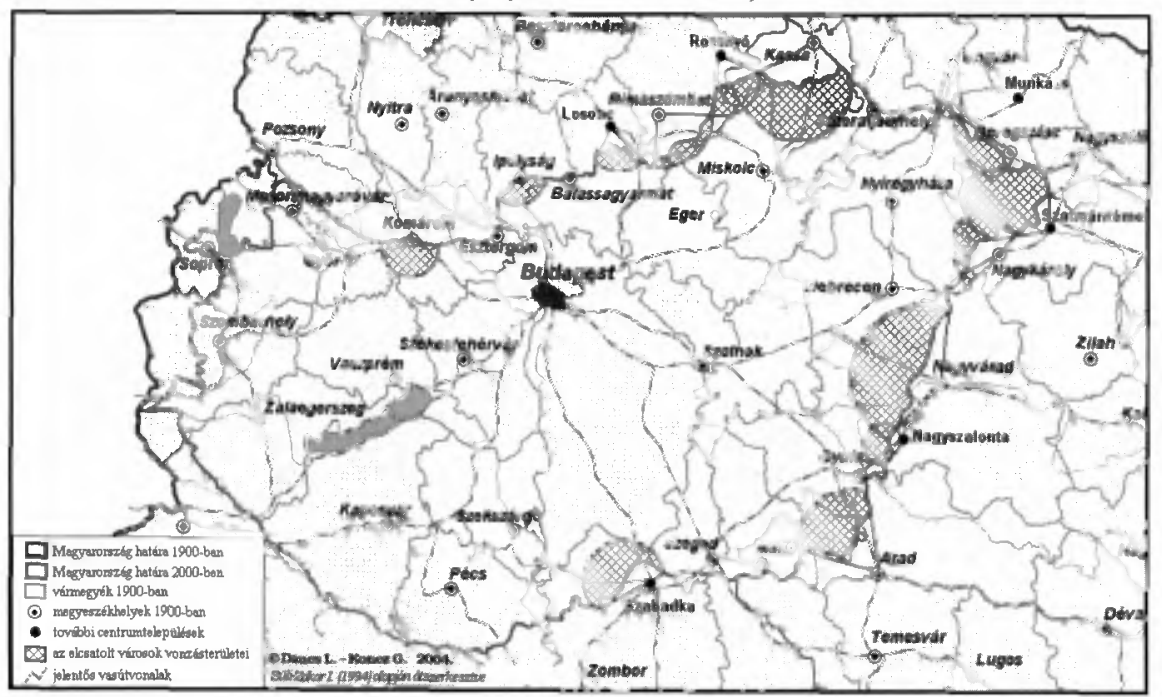

Forrás: Szerkesztette Dancs L.-Koncz G. (2004). 
A Magyar Köztársaság vélhetően távlatosan külsö, ún. schengeni határain, mindenekelött a $137 \mathrm{~km}$ hosszú magyar-ukrán, a $174 \mathrm{~km}$-nyi magyar-szerb és a $345 \mathrm{~km}$ hosszú magyar-horvát határszakaszokon - de több határtérségben is - a történelmileg is motivált hátrányos következmények minimalizálásában, a határon átívelö kapcsolatok erösítésében játszhatnak megkülönböztetett szerepet azok a nagy eurorégiós szervezetek és egyéb interregionális szervezödések, amelyeknek a határon átnyúló együttmüködésben meglévő valós vagy potenciális funkciói akkor sem lebecsülendök, ha tevékenységük formális keretei esetenként még erösebbek, mint müködésük tényleges tartalmi jellemzői. Az államhatárokon átivelő határközi struktúrák intézményi keretei Magyarországon gyakorlatilag minden határszakaszon kiépültek, ami egyben azt is jelzi, hogy a határon átnyúló együttmüködések erösítését követelik meg a hasonló természet- és településföldrajzi pozíciók és adottságok, a hajdan volt történelmi alapok és a határ túloldalán élö magyarsággal ápolandó kapcsolatok is, amelyek fenntartásában és erősítésében fontos szerepet játszanak az intézményesült határközi interregionális szervezetek, ún. eurorégió típusú határközi struktúrák, melyek száma az Európai Unióban jelenleg mintegy kétszáz, Magyarország államhatárai mentén pedig tizennyolc (1., 3. ábra, 1. táblázat).

$\mathrm{Az}$ interregionális szervezetek magas száma természetesen önmagában még nem garancia a tartalmas tevékenységre, inkább csak lehetôség, olyan intézményi keret, amely optimális esetben hatékony szerepet játszhat a határrégiók együttműködésében. A határközi struktúrák intézményi modelljei közül funkciójuk, méretük, területiségük, térszerkezeti elhelyezkedésük és kapcsolataik alapján három főbb típus emelhető ki:

1) Munkaközösség - az eurorégiónál egyszerübb szervezeti felépítésủ vagy kevésbé integrált, országokat és tartományokat magában foglaló laza, alacsonyabb kompetencia-szintü, transznacionális jellegü országhatárokon átívelö együttműködés, érdekközösség. A nagy kiterjedésủ szervezeti formát tekintve Magyarország két esetben - Alpok-Adria Munkaközösség (1978) és a Duna Menti Tartományok Munkaközössége (1990) - érintett.

2) Eurorégió - államhatárokat áthidaló, legmagasabb szintü, legtöbb hatáskörrel és funkcióval rendelkezö, legfejlettebb együttmüködési forma, határközi struktúra, amely területiség és térszerkezeti kapcsolatok alapján két nagy csoportra osztható:

- Nagyrégiós modell - nagyívủ határon átnyúló középszintü, tartományi és/vagy megyei, ún. trans-border típusú együttmüködések. Magyarországot három ilyen határközi struktúra érinti: Kárpátok Eurorégió (1993), Duna-KörösMaros-Tisza Eurorégió (1997), West/Nyugat-Pannónia Eurorégió (1998).

- Kisrégiós modell - megyék, kistérségek és/vagy városok, városi vonzáskörzetek közötti, ún. cross-border típusú intézményesült együttmüködéseket foglal magában. Számuk Magyarországon tizenhárom. Létrejöttük sorrendjében a következök: Duna-Dráva-Száva Euroregionális Együttmüködés (1998), VágDuna-Ipoly Eurorégió (1999), Ipoly Eurorégió (1999), Neogradiensis Eurorégió (1999), Sajó-Rima Eurorégió Határon Átnyúló Együttmüködés (2000), INTERREGIO (2000), Kassa-Miskolc Eurorégió (2000 és 2004), 
Hármas Duna-Vidék Eurorégió (2001), Dráva-Mura Eurorégió (2001), Bihar-Bihor Eurorégió (2002), Hajdú-Bihar-Bihor Eurorégió (2002), IsterGranum Eurorégió (2003), Zemplén Eurorégió (2004).

3) Rövid tóvú, projektszintü és egyéb településközi, ritkán kistérségi együttmúködések - eseti, ,ad hoc” jellegú alkalmi kooperációk, valamint egyéb jogi alapokon vagy anélkül múködő (testvértelepülési) kooperációk, regionális méretủ térben szervezödő, de alacsony integritással bíró, formális szerepkörü „névleg eurorégiók", amelyek konkrét, gyakran átmeneti jelleggel jönnek létre, számuk igen magas, s állandóan változik (Rechnitzer 1999).

Mindent együttvéve az eu- vagy eurorégiók pragmatikus, definitív megfogalmazásban Magyarországra vonatkoztatva sem jelentenek mást, mint európai kitekintésben, azaz, hogy a határ menti együttmüködés hagyományos és legeredményesebb formái, amelyek földrajzilag két vagy több ország érintkezö területeit foglalják magukban, és két vagy több állam kormányai és/vagy helyi (regionális) önkormányzatai megállapodást kötnek abból a célból, hogy összehangolják tevékenységüket a határ menti térségek eredményesebb fejlesztése érdekében (Éger 2000).

A határkutatók a rendszerváltást követően helyesen ismerték fel, hogy a hatékony és eredményes határon átnyúló struktúrák felállítása Kelet-Közép-Európa országaiban is szükséges. A létrejövő interregionális struktúrák jelentősége - egyikük igen találó megfogalmazása szerint - mindenekelőtt abban rejlik, hogy a határ menti együttmüködés interregionális szervezeteinek a létrejötte és gyors fejlödése a „térségeknek politikai tartalmat és szerepet biztositott, továbbá új európai területi dimenziók kialakítását eredményezte" (Scott 1997, 119). Ez az új területi dimenzió már azokat az együtt éló határrégiókat jeleníti meg, ahol széles körü kapcsolatok alakulnak ki a gazdasági-társadalmi-kulturális élet legkülönbözöbb területein.

A Magyar Köztársaság külső határai mentén keletkező hátrányos helyzet minimalizálásában, a határon átivelö kapcsolatok erősítésében játszhatnak megkülönböztetett szerepet többek között azok az eurorégiók és egyéb interregionális szervezódések, amelyek már eddig is szép számmal jöttek létre az ország határrégióiban. A határon átnyúló együttmúködésben meglévő valós vagy potenciális funkcióik akkor sem lebecsülhetök, ha tevékenységük formális keretei olykor még erősebbek, mint müködésük tényleges tartalmi összetevői. Ebben a kapcsolatépítésben rendelkeznek ígéretes kilátásokkal a különféle intézményesült együttmüködési formák, az eurorégió típusú határközi struktúrák, amelyek jelenleg már lefedik Magyarország minden határszakaszát (3. ábra). 


\section{3. ÁBRA}

Eurorégiók és határon átnyúló regionális együttmüködések Magyarország részvételével 2004-ben(Euroregions and Cross-border Regional Co-operations with Hungarian

Participation in 2004)

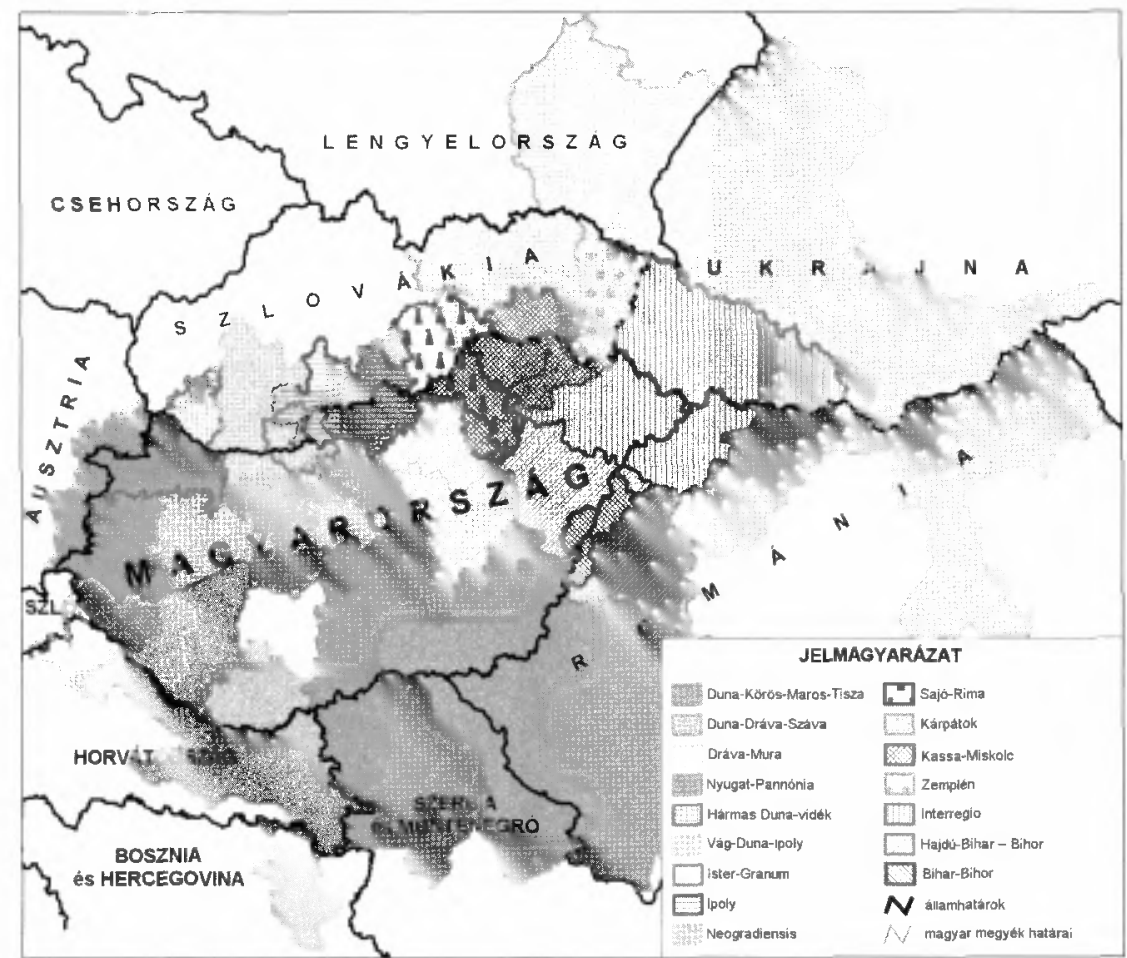

Forrás: Szerkesztette Dancs L.

A számtalan euroregionális szervezet, eurorégió (nagyrégió) és egyéb kisrégió vagy kvázi eurorégiós jellegü szervezódés, ún. eurorégió típusú struktúrák közül Magyarország országhatárai mentén is szép számmal jöttek létre integrációs tömörülések. A határ menti együttműködés legmagasabb szintjét jelentő nagy eurorégiós kooperációk száma Magyarországon ma már három, de több eurorégió, s még több eurorégió típusú együttműködés szerveződése van folyamatban. A már meglévő három magyarországi (nagyrégiós jellegü) eurorégiós egyuittmüködés közül kettö múködési területe - a térségben elsỏkẻnt 1993. február 14-én létrejött Kárpátok Eurorégió Interregionális Szövetség (Kárpátok Eurorégió), illetve az 1997. november 21-én Szegeden alakult Duna-Körös-Maros-Tisza Regionális Együttmüködés a kelet-magyarországi határvidék, az ország északkeleti, keleti és délkeleti határrégióit, míg a harmadik az 1998. október 7-én létrejött West/Nyugat-Pannónia Eurorégió a nyugati kapcsolódási pontnak számító magyar-osztrák határ menti területeket foglalja magában. A két munkaközösségi típusú együttmüködést Alpok-Adria Munkaközösség, Dunamenti Tartományok Munkaközössége - nem 
számítva, összesen még további 16 különféle nagyrégiós és kisrégiós euroregionális szervezet található Magyarországon (1. táblázat).

\section{TÁBLÁZAT}

A határ menti együttmüködési szervezödések fontosabb adatai, 2004 (Major Data of the Cross-border Cooperation Organisations, 2004)

\begin{tabular}{|c|c|c|c|c|c|}
\hline $\begin{array}{l}\text { Interregionális } \\
\text { szervezödés }\end{array}$ & $\begin{array}{l}\text { Az alapi- } \\
\text { tás éve }\end{array}$ & $\mathrm{km}^{2}$ & $\begin{array}{c}\text { ület } \\
\text { ebből: a } \\
\text { magyar } \\
\text { területek } \\
\text { aránya, } \\
\% \\
\end{array}$ & $\begin{array}{l}\text { Népesség } \\
\text { ezer fö }\end{array}$ & $\begin{array}{l}\text { Az együtt- } \\
\text { müködés- } \\
\text { ben részt } \\
\text { vevö terü- } \\
\text { leti egysé- } \\
\text { gek száma }\end{array}$ \\
\hline Kárpátok Eurorégió & 1993 & 161192 & 16,2 & 16051 & 20 \\
\hline $\begin{array}{l}\text { Duna-Körös-Maros-Tísza } \\
\text { Eurorégió }\end{array}$ & 1997 & 71636 & 25,0 & 5600 & 9 \\
\hline West/Nyugat-Pannónia Eurorégió & 1998 & 15148 & 78,0 & 1265 & 4 \\
\hline Duna-Dráva-Száva Eurorégió & 1998 & 28284 & 37,3 & 2454 & $11^{4}$ \\
\hline Neogradiensis Eurorégió & 1999 & 4668 & 54,3 & 364 & 4 \\
\hline Ipoly Eurorégió & 1999 & 6325 & 45,1 & 543 & $4^{5}$ \\
\hline Vág-Duna-Ipoly Eurorégió & 1999 & 14283 & 65,5 & 2082 & 6 \\
\hline Kassa-Miskolc Eurorégió & 2000 & 14000 & 51,8 & 1512 & 2 \\
\hline Sajó-Rima Eurorégió & 2000 & 10621 & 68,2 & 930 & 4 \\
\hline Interre & 2000 & 23221 & 25,6 & 2229 & 3 \\
\hline Hármas Duna-vidék Eurorégió & 2001 & 6162 & 68,3 & 697 & 4 \\
\hline Dráva-Mura Eurorégió & 2001 & n. r. $^{2}$ & 62,4 & 157 & 9 \\
\hline Hajdú-Bihar-Bihor & 2002 & 13755 & 45,1 & 1176 & 2 \\
\hline Bihar-Bihor & 2002 & 1760 & 33,3 & 109 & $2^{3}$ \\
\hline Ister-Granum Eurorégió & 2003 & 2000 & 60,4 & 200 & $9^{6}$ \\
\hline Zemplén Eurorégió & 2004 & 6282 & 28,2 & 200 & $4^{1}$ \\
\hline
\end{tabular}

Megjegyzés: 1) A szervezỏdést kistérségek (szlovák formula szerint mikrorégiók) alkotják; 2) A szervezổés tagjai egymással nem szomszédos települési önkormányzatok, a terület ezért nem releváns; 3) A tagszervezetek önszervezödő kistérségek, amelyek magyar oldalon 19 település, román oldalon 17 (társközségekkel együtt 40) telepuulést tömörítenek; 4) A közigazgatási területi egységeken (megyéken) kívül a szervezet tagjai városok, község és különféle kamarák; 5) Továbbá hat civil szervezet is tagja; 6) Kilenc kistérség (mikrotérség) területén összesen 100 települési önkormányzat.

Forrás: Horváth (2005) alapján részben saját korrigált számítás.

A különféle intézményesült határközi struktúrák, eurorégiók és egyéb interregionális szervezetek magas száma is jelzi, hogy az 1989/90-tól kibontakozó keletközép-európai rendszerváltó folyamat és az európai integrációs folyamatok kiterjedésének egyik következménye volt az új államok létrejötte, az államhatárok elválasztó jellegének a mérséklődése, egyszersmind a határrégiók szerepkörének a bỏvülése. A határon átnyúló ủj különféle interregionális szervezỏdések létrejöttének egyik nagy előnye ugyanis, hogy azokat ma már nem korlátozzák sem az egykori, sem a meglévő államhatárok, és így akár több ország területeit magukban foglaló régiók is létrejöhettek. Miután pedig az EU-ban kiemelt prioritást élvez az elmaradott határ menti régiók fejlesztésének és felzárkózásának elősegítése, ezért a hatá- 
rokon átívelő regionális szerveződéseknek a közös fellépés lehetősége miatt még inkább létérdeke az együttmüködés, mivel maguk is komolyan befolyásolhatják a kapcsolatok alakulásának irányát, és szervező tevékenységükkel jelentősen erösíthetik a szerzödő felek határterületeinek kohézióját.

$\mathrm{Az}$ euroregionális szervezetek mind a nyugat-európai, mind pedig a kelet-középeurópai országok határrégióiban többé-kevésbé hasonló indíttatásból jöttek létre és terjedtek el, törekvéseik, feladataik, s egyáltalán a tevékenységüket meghatározó motivációk nagyon hasonlóak, mondhatni azonosak a bővülö Európában. A keletközép-európai változások és az európai integrációs folyamatok mintegy szerves velejárójaként a határon átnyúló együttmüködések motivációja Magyarország esetében is elsősorban a belső és külső erőforrások közös hasznositása, az uniós regionális támogatások megszerzése, az integráció erősítése, a határ menti fejlettségbeli különbségek csökkentése, a perifériák felzárkóztatása, a történeti-etnikai feszültségek és problémák enyhítése, a korábban összetartozó térszerkezeti funkciók „egyesítése", az új regionális gazdasági tér létrehozása és kohéziója, az ún. euroregionális szemlélet és a regionális identitás erősítése, mely szerint a jövő Európája nemcsak a nemzetállamok, hanem az azonos gazdasági érdekeltségủ (határ menti) területekböl kialakított „régiók Európájaként” is értelmezhető. A határok meghaladásából, az euroregionális együttmüködésből számos elönye származhat nemcsak a határ menti térségeknek, de a nemzetállamoknak is (Horváth 2001; Baranyi 2004b).

Magyarország keleti államhatárai mentén tevékenykedő két hatalmas kiterjedésủ eurorégió, a Kárpátok Eurorégió (161 ezer km², 16 millió lakos) és a Duna-KörösMaros-Tisza Eurorégió (71,5 ezer km² , 5,6 milliós népesség) eddigi müködésének eredményességével kapcsolatos megitélés ellentmondásos (4. ábra). Mindkét nagyrégiós euroregionális szervezet esetében közös jellemzőként mondható el ugyanis, hogy különböző múltbeli és újkeletű politikai, gazdasági-társadalmi, etnikai okok - s nem csak a területiség, a túlméretezettség - miatt ma még nem képesek azokat a funkciókat ellátni, amelyeknek a fejlettebb nyugat-európai térségek nagy interregionális szervezetei már sokkal sikeresebben felelnek meg. Különösen problematikusnak tekinthető a Kárpátok Eurorégió tevékenysége. Az öt ország (Magyarország, Lengyelország, Ukrajna, Szlovákia, Románia) amúgy is periférikus, öröklött és újkeletủ problémákkal terhelt és elmaradott területeket magában foglaló, perifériák találkozásában fekvő ún. Kárpáti Régió (Illés 2002) térségében tevékenykedő Kárpátok Eurorégió mintegy kéttucat, olykor nem is szomszédos országokkal érintkező közigazgatási egységére kiterjedően, pusztán túlméretezettsége miatt is már-már a működésképtelenség felé sodródik. Az egyre inkább formális jellegü, ún. bizottsági, nem pedig projekt típusú interregionális szervezet működési zavaraihoz hovatovább nyilvánvalóan hozzájárult azoknak a külpolitikai - föként biztonságpolitikai - tényezöknek a háttérbe szorulása, amelyek az eurorégió alapításakor, a kilencvenes évek első felében még meghatározó szerepet játszottak a szervezet életre hívásában.

A nagyrégiós modellek közül egyedül a West/Nyugat Pannónia Eurorégió tủnik a legéletképesebb szervezetnek. Az Eurorégió viszonylag optimális területével (15,2 ezer $\left.\mathrm{km}^{2}\right)$ és lakosságával (1,3 millió fö) kiválóan tölti be a nyugati irányú 
stratégiai kapcsolódási szerepet a három magyarországi (Győr-Moson-Sopron, Vas, Zala) megye és egy ausztriai tartomány (Burgenland) közötti sokszintủ kooperációs kapcsolatrendszerben. A nagy eurorégiós szervezetek helyett, sokszor azok keretei között a kisebb interregionális szerveződések mozgékonyságuk és a közvetlenebb egymáshoz kapcsolódás, a szorosabb kötódés és az együvé tartozást megalapozó identitás miatt is számos területen hatékonyabban képesek szolgálni a határon átíveló kapcsolatok ügyét, mint a hatalmas, nagy kiterjedésủ eurorégiós szintủ kooperációk.

Számos jel mutat arra, hogy a két nagy kelet-magyarországi eurorégió helyett vagy annak megújításával, mindenekelött a Kárpátok Eurorégió területén, azaz a szomszédos határ menti régiók különböző területi szinteken történő összefogásával, a közös érdekek és érdekeltség felismerésével a mai határon átnyúló kapcsolatoknál jóval működőképesebb együttmüködések jöhetnek létre, különösen, ha képesek lesznek a hagyományos bürokratikus és gyakorta formális "bizottsági típusú" együttmúködésről a konkrét, gyakorlati jellegü hatékony „projekt típusú” mủködésre átállítani tevékenységüket. Ily módon ezek a nagyívú eurorégiók is a határon átívelő együttmüködések eredményes formái lehetnek. Az ország egészét tekintve máris számos határrégióban rajzolódnak ki, föként a centrumvárosok közötti szorosabb interregionális (kisrégiós) együttmüködés földrajzi keretei (Id. 5., 6. ábra).

\section{4. ÁBRA}

A Duna-Körös-Maros-Tisza és a Kárpátok Eurorégió, 2004

(The Danube-Körös-Maros-Tisza and the Carpathians Euroregion, 2004)

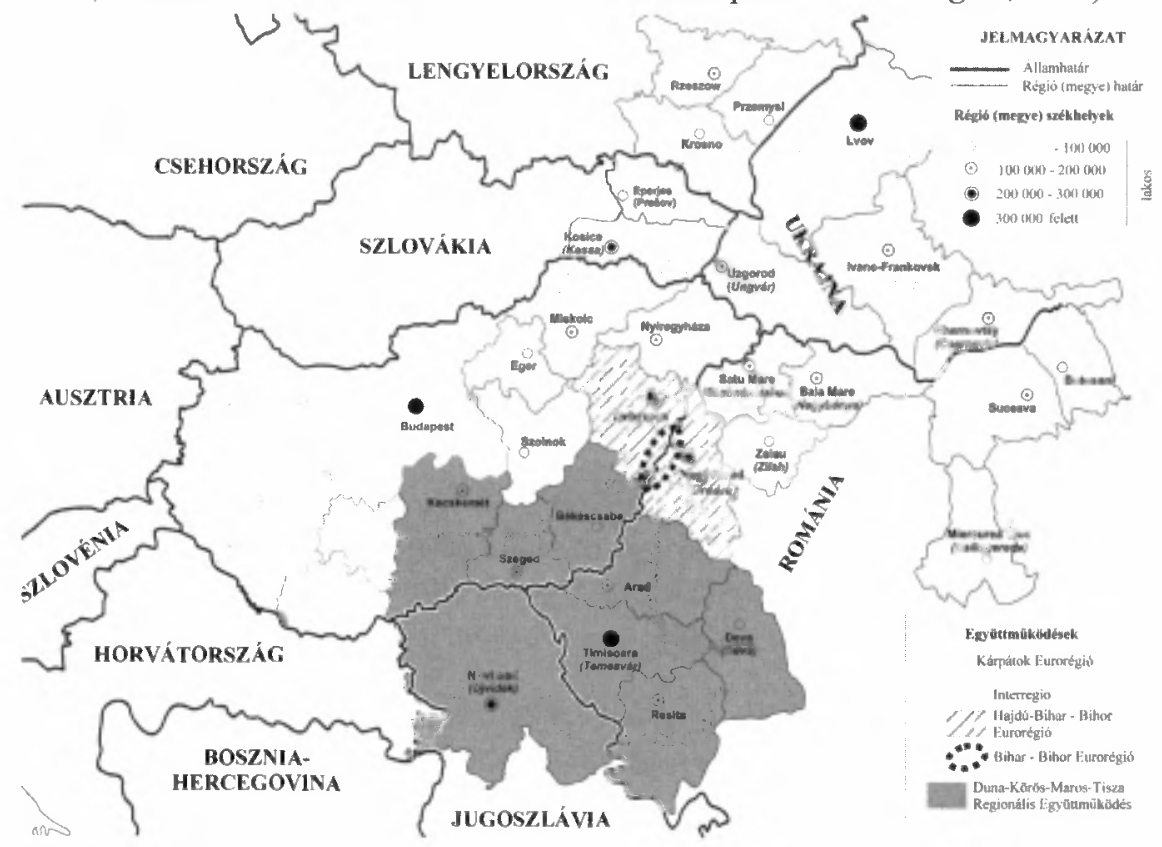

Forrás: Hardi T. alapján szerkesztette Dancs L. 


\section{Paradigmaváltás - együttmüködés határok nélkül}

Az európai integráció erősödésével, a Schengen-folyamat kiteljesedésével Magyarország esetében a Schengeni Végrehajtási Egyezmény 2008-tól történt teljes körủ bevezetésével - gyökeres változás, ha tetszik paradigmaváltás várható a határon átnyúló kapcsolatok jellegét, tartalmát és formáit illetően. A határmentiség új dimenziói elsősorban a kisebb, konkrét bi- és trilaterális intézményesült interregionális együttmüködések előtérbe kerülését jelentik, mindenekelött a schengeni belső határok mentén. A nagyivü határközi szervezeti rendszerek (eurorégiók) keretében és/vagy mellett felértékelődik a kisebb léptékü határ menti együttmüködések, kistérségkistérség, kistérség-város, város-város kapcsolatok, város- és településszövetségek kvázi „mini-eurorégiók” -, valamint a nagy- és középvárosok „kapuvárosi” (gateway) tranzitfunkcióinak és az egyéb településközi kapcsolatoknak a szerepe.

A már megvalósult határon átnyúló interregionális egyuittmüködésekben, illetve a potenciális eurorégiók szerveződésében az ország államhatárai mentén ma már erősebben érvényesülnek a nagyvárosi, kistérségi vagy éppen megyei érdekek, mint a kevésbé vagy egyáltalán nem létező magasabb szintü regionális akaratok. A kisebb, korábban már felsorolt euroregionális együttmüködések és a hozzájuk kapcsolódó vállalkozói övezetek, ipari parkok stb. müködési területén, a rendszerváltás óta eltelt időszakban a határon átnyúló kapcsolatok fejlődése pozitiv irányt vett. Az intézményi keretek között zajló kulturális, oktatási kapcsolatok egyaránt bővülttek, és jelentős elmozdulás történt a gazdasági kooperációk terén is. A biztató jelek és perspektívák ellenére az újonnan formálódó kisebb euroregionális szervezetek és egyéb határ menti együttmüködések még nem hoztak igazi áttörést a kapcsolatépítésben.

$\mathrm{Az}$ interregionális együttmüködés egyéb lehetséges szintjeit tekintve a magyar területi tudományok képviselői közül már a kilencvenes évek derekán voltak olyanok, akik megkülönböztetett hangsúlyt helyeztek a határ menti nagyvárosoknak, regionális centrumoknak és paracentrumoknak a nemzetközi, illetőleg regionális-interregionális együttmüködésben jảtszott szerepére, valamint a potenciális eurorégiók létrejöttében várható közremüködésére (Golobics 1996). Később az osztrák-magyar határ menti együttmüködés, valamint a Nyugat-Dunántúl egészére vonatkozó vizsgálatok alapján a potenciális eurorégiók összekapcsolásának lehetséges szintjeit illetően olyan fontos és újszerü megállapítások születtek, amelyek érvényessége feltétlenül kiterjeszthető az ország keleti államhatárai mentén formálódó együttmúködésekre is. A legújabb tudományos elemzések és tapasztalatok egyaránt amellett szólnak, hogy az országhatárok mentén „,mini eurorégiók” hálózatának a létrejöttét célszerủ ösztönözni, amelyek elsődlegesen település-település, város-város, kistérség-kistérség, kistérségjárás szintjén segítik elő az együttmüködéseket (Rechnitzer 1999) (5. ábra).

Az új típusú, kisebb kiterjedésủ, egyszersmind mozgékonyabb és konkrétabb együttmüködések sokkal inkább tartós alapját, szilárd pillérét teremthetik meg az eurorégiók megszerveződésének. Nyilvánvaló ugyanis, hogy bármilyen meglévő vagy éppen szerveződő (potenciális) eurorégió valós regionális fejlesztő hatásokat csak akkor képes 
kifejteni, ha a közremüködő települések és térségek az együttmüködésben megtalálják a saját és közös érdekeiket. Az érdekérvényesités konkrét képviseletére pedig leginkább a határ menti települési és térségi önkormányzatok, középszintü intézmények és szervezetek az alkalmasak (Hardi 2004).

\section{5. ÁBRA}

Formálódó határrégiók és új interregionális együttmüködések (Potential and Shaping Border Regions and Interregional Co-operations)

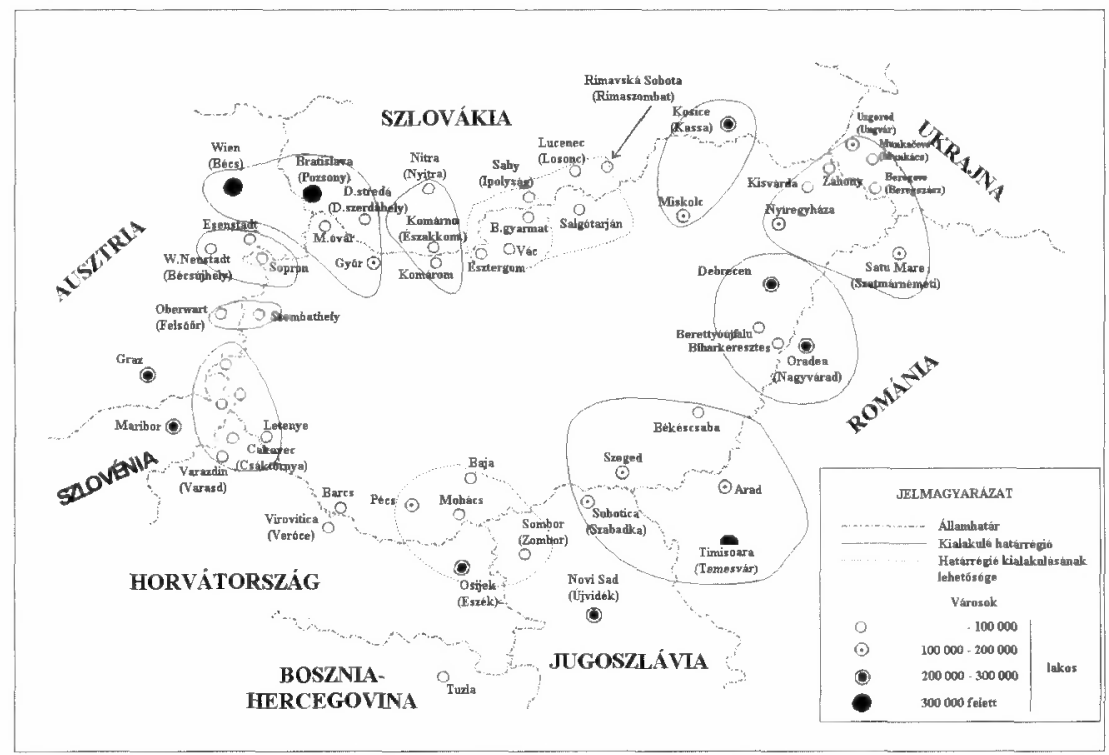

Forrás: Szerkesztette: Hardi T.-Dancs L.

Az elmondottak is azt támasztják alá, hogy a határon átnyúló regionális együttműködésben az euroregionális szerveződések mellett - akár annak keretei között meghatározó szerephez jutnak a határrégiók egyes kistérségei, településegyüttesei és -szövetségei, de leginkább a határ menti nagyvárosok, az ún. centrumvárosok. Ezért is annyira fontos, hogy a nagy ívu szervezeti rendszerek (eurorégiók) létrehozásán túl a kistérség-település, város-város érintkezések vagy városszövetségek jöjjenek létre. Ebben a dimenzióban a kihívásoknak fỏként a regionális centrumvárosok és egyes paracentrumok felelnek meg, igaz ma még eltérö színvonalon (Györ, Komárom, Balassagyarmat, Salgótarján, Miskolc, Nyiregyháza, Debrecen, Békéscsaba, Szeged, Pécs, Dunaszerdahely, Pozsony, Nyitra, Komárno, Ipolyság, Losonc, Kassa, Ungvár, Szatmárnémeti, Nagyvárad, Arad, Temesvár, Szabadka, Eszék stb.). Az északkelet-magyarországi határszakaszon - de a keleti és részben a déli határrégiókban is - hasonló nagyságú, szerepkörü, korábban egymást jól kiegészítő városgyürük találhatók a határ két oldalán, ezek hálózatba szervezése - elsőként az infrastrukturális rendszerek megújitásával - lehetséges, ami önmagában is nagy lendületet biztosítana a határ menti együttműködések ügyének (6. ábra). 


\section{6. ÁBRA}

Potenciális város-város és város-falu együttmüködések Magyarország határtérségeiben

(Potential Inter-town Co-operations and Co-operations between Towns and Villages in the Border Regions of Hungary)

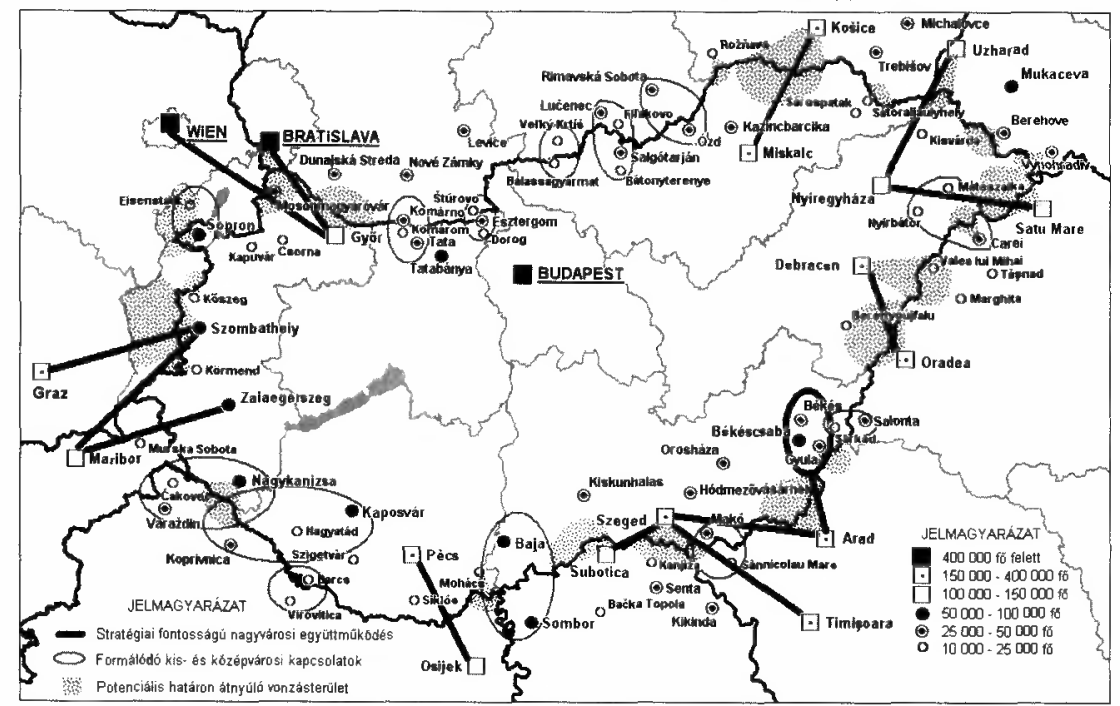

Forrás: Szerkesztette Balcsók I.-Koncz G. (2008).

\section{7. ÁBRA}

A Centrope region elhelyezkedése

(Location of the Centrope Region)

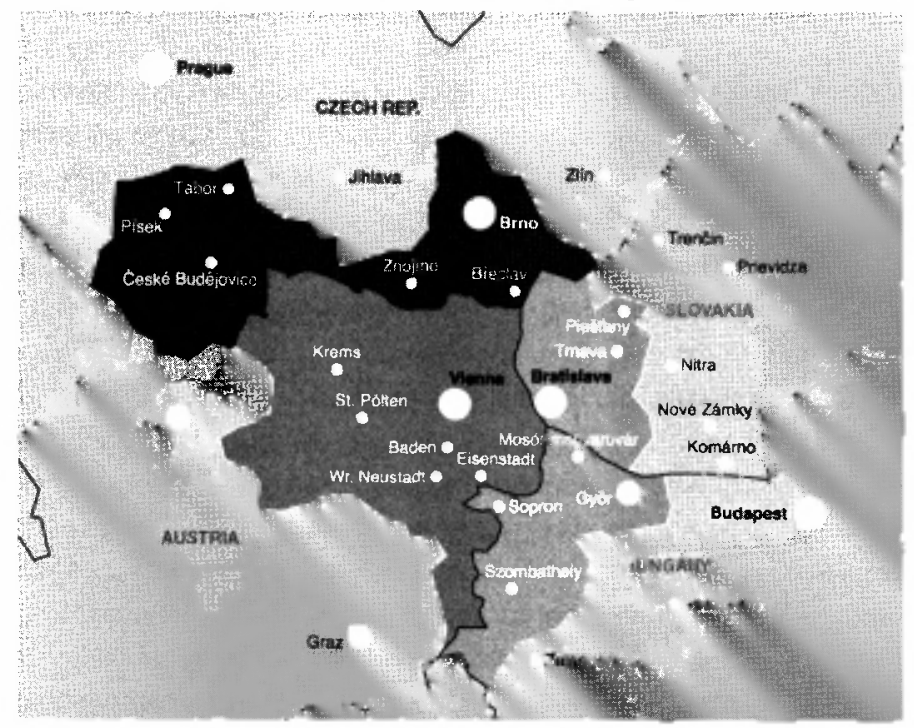

Forrás: www.centrope.com 
Városközi és városok közötti kapcsolaton alapuló, nemcsak intézményesült, hanem projektszintü együttmüködések számos helyen kimutathatók Magyarország más határrégióiban is, többnyire inkább ott, ahol a funkcionális együttmüködésnek erős hagyományai, szilárd történelmi alapjai és felttételrendszere alakult ki, s a kapcsolatok működtetéséhez rendelkezésre állnak a megfelelö szintű és érdekeltségü partnerek. Ilyen funkcionális területek kölcsönös érdekeltsége alapján formálódó konkrét és hatékony együttmüködésre való készség mutatkozik meg újabban pl. a magyarosztrák-szlovák közvetlen határtérségben - az osztrák-szlovák-cseh határrégiókra átnyúlóan -, ahol elsősorban Bécs hagyományosan kiemelkedö gazdasági, társadalmi és innovációs, illetve az ugyancsak igen erős Pozsony és a térségre is kisugárzó hatással is bíró Brno, de a súlyánál és regionális szerepkörénél fogva ide sorolható Györ bázisán és a közeli nagy- és középvárosok kapcsolatára építve nagyon szilárd projektszintủ együttmüködés formálódik Centrope region néven (7. ábra).

\section{Összegzés}

A határmentiségben és a határon átnyúló kapcsolatokban az európai integrációs és globalizációs folyamatok kiteljesedésével várhatóan egy kettös tendencia figyelhető meg. Az egyik tendencia abban mutatkozik meg, hogy a különféle eurorégiós és interregionális szervezetek - lassan csökkenő szerepkörrel - a jövöben is a határ menti együttmüködések, illetve a határon átnyúló kapcsolatok fejlesztésének eredményes formái maradnak, különösen ami a szomszédos országok területi és fejlettségi különbségei mérséklésének a lehetôségeit illeti. A korábban intézményesült eurorégió típusú határközi együttmüködések - azon túl, hogy elősegíthetik az uniós források megszerzését és hatékonyabb felhasználását - jelentős mértékben hozzájárulhatnak Magyarország politikai és gazdasági pozícióinak átrendezéséhez is a Kárpát-medencében.

Az elöbbivel egyidejüleg kibontakozó másik tendencia, hogy a nagyívủ multinacionális határközi szervezeti rendszerek, a nagyrégiók (pl. Kárpátok Eurorégió) mellett - vagy helyett - várhatóan felértékelödik a kisebb léptékü intézményi formák, kistérségi, városközi, településszövetségi stb. kapcsolatokon alapuló kisrégiós (HajdúBihar-Bihor Eurorégió, Bihar-Bihor Eurorégió), az ủn. minieurorégiós interregionális együttmüködések, valamint a határ menti nagy- és középvárosok kapuvárosi (gateway) és tranzitfunkcióinak, illetve egyéb település- és intézményközi kapcsolatoknak a szerepe. A jövőt tekintve tehát a hatékonyabb határokon átnyúló kapcsolatépités érdekében a gyakorta formális tevékenységet folytató, hatalmas területủ nagyrégiós szervezetek - mindenekelőtt a Kárpátok Eurorégió, s részben a DunaKörös-Maros-Tisza Eurorégió - gyökeres megújulása, szervezeti struktúrájának átalakítása és a kisebb léptékü, határközi struktúrák, projektjellegü megyei és/vagy kistérségi együttmüködések szerepének növelése a közeljövő nagy kihívása, különösen hogy a Schengen-folyamat pozitív következményeként föként a belső határok mentén 
radikálisan csökkent az államhatárok elválasztó szerepe, kedvezőbbé vált és jelentősen bővült az interregionális együttmüködések feltételrendszere.

Az euroregionális és interregionális szervezetek optimális körülmények között az országhatárok mentén eröteljesebben akkumulálódó területi és fejlettségi különbségek mérséklésének, valamint a periféria-jelleg csökkentésének a hatékony eszközei lehetnek. Ez a kiegyenlitö hatás különösen fontos szempont Kelet-Közép-Európában, s nem utolsósorban a kelet-magyarországi határtérségekben, hiszen itt nagy jelentőséggel bír a jogos igény, hogy a rendszerint periférikus, olykor halmozottan hátrányos helyzetủ határ menti területek mielöbb felzárkózhassanak, sőt integrálódhassanak a fejlettebb területekhez.

A különbözö határközi együttmüködések, struktúrák, interregionális szervezetekfơként az újabb kisrégiós szervezödések - minden problémájuk ellenére a határon átíveló kapcsolatok olyan új intézményesült keretei, amelyek eredményesen szolgálhatják az uniós források megszerzését, hatékonyabb felhasználását, mindenekelött pedig a közvetlen kapcsolatok és helyi eröforrások kiaknázásában rejlő lehetöségeket, amelyek mérsékelhetik Magyarország európai uniós csatlakozásával létrejött schengeni külső határok kedvezőtlen hatásait, s nem utolsósorban hozzájárulhatnak a határrégiók közötti összekötö (híd-) szerep erösödéséhez, a Trianonban széttöredezett térszerkezeti egységek "újraegyesitéséhez", távlatosan pedig egy új Kárpát-medencei transznacionális makroregionális gazdasági térség létrejöttéhez.

Végül az eredményes interregionális együttmüködés egyik fontos elöfeltétele, hogy a fejlesztésében érintett tudományos, politikai, gazdasági, társadalmi, civil és egyéb szervek/szervezetek közremüködésével készüljenek tartalmas és megvalósítható közös fejlesztési dokumentumok a szomszédos határrégiókra vonatkozóan. Igen fontos azonban, hogy a fejlesztési dokumentumok többek között legyenek tekintettel a perifériák eltérỏ lehetőségeire, a kapu- és közvetítőszerepek, az ún. kapuváros (gateway) funkciók kialakítására, a határon átnyúló térségi integrációs, a nemzetiségi és társadalmi kapcsolatok kérdéseire is.

\section{Irodalom}

Balcsók, I.-Baranyi B.-Dancs, L.--Koncz, G.-Raffay, Z.-Szabó, Gy. (2005) Hungarian-Romanian and Hungarian-Ukrainian border regions as areas of co-operation along the external borders of Europe. Discussion Papers Special. Centre for Regional Studies, Pécs.

Baranyi B. (2002) Euroregionális szervezetek és új interregionális szerveződések Magyarország keleti államhatárai mentén. - Magyar Tudomány. 11. 1505-1518. o.

Baranyi B. (2004a) Gondolatok a perifériaképzódés történeti elözményeiról és következményeiról. - Tér és Társadalom. 2. 1-21. o.

Baranyi B. (2004b) A határmentiség dimenziói. Magyarország és keleti államhatárai. Dialóg Campus Kiadó, Budapest--Pécs.

Baranyi B. (2007) A határmentiség dimenziói. 2. jav., böv. kiad. Dialóg Campus Kiadó, Budapest-Pécs.

European Comission (1997) Practical Guide to Cross-border Cooperation. Regional Policy and Cohesion. 2 nd Edition. European Comission, Gronau.

Éger Gy. (2000) Regionalizmus, határokés kisebbségek Kelet-Közép-Európában. Osiris, Budapest.

Golobics P. (1996) A határ menti térségek városainak szerepe az interregionális együttmúködésben Magyarországon. - Pál Á.-Szónokyné Ancsin G. (szerk.) Határon innen - határon túl. JATE Gazdasági Földrajzi Tanszék, JGYFT Földrajzi Tanszék, Szeged. 224-230. o. 
Hardi T. (2004) Az államhatárokon átnyúló régiók formálódása. - Magyar Tudomány. 9. 991-1001. o.

Horváth Gy. (szerk.) (2000) A régiók szerepe a bövülö Európai Unióban. MTA Regionális Kutatások Központja, Pécs.

Horváth Gy. (2001) Regionális támogatások az Európai Unióban. Osiris, Budapest.

Horváth Gy. (2004) Strukturális politika és a kelet-közép-európai régiók. - Terïleti Statisztika. 3. 236-251. o.

Horváth Gy. (2005) A Kárpát-medencei régiók közös kohéziós politikájáról. - Baranyi B. (szerk.) Közelitések. A határon átnyúló kapcsolatok kilátásai és a mezógazdaság regionális kérdései az Európai Unió keleti peremén. MTA Regionális Kutatások Központja, Debrecen. 13-28. o.

Illés I. (2002) Közép-és Délkelet-Európa az ezredfordulón. Atalakulás, integráció, régiók. Dialóg Campus Kiadó, Budapest-Pécs.

Novotny G. (2003) Határon átnyúló regionális hálózatok Európában. PhD-értekezés, Kézirat, Pécs.

Rechnitzer J. (1999) Határ menti együttmủködések Európában és Magyarországon. Az osztrảk-magyar határ menti együttmúködések a kilencvenes években. - Nárai M.-Rechnitzer J. (szerk.) Elválaszt és összeköt - a határ. MTA Regionális Kutatások Központja, Pées-Gyór. 9-128. o.

Scott, J. (1997) A határmenti együttmüködés nemzetközi rendszerei. - Tér és Társadalom. 3. 117-131. o.

Sucha, M.S. (1995) Eurorégiók Németország és az Európai Unió keleti határain. - Deutschland. Június. 28-31. o.

Tóth J. (1996) A Kárpát-medence és a nemzetközi regionális együttmüködés. - Pál Á.-Szónokyné Ancsin G. (szerk.) Határon innen - határon túl. JATE Gazdasági Földrajzi Tanszék, JGYFT Földrajzi Tanszék, Szeged. 27 43. o.

\section{A PARADIGM SHIFT IN CROSS-BORDER RELATIONS}

\section{BÉLA BARANYI}

The strengthening of the European integration - including the unfurling of the Schengen process - will probably lead to a radical change, in other words a paradigm shift as regards the character, content and forms of cross-border relations. The new dimensions of the border relations mean the growing importance of smaller scale, bi- and trilateral institutionalised interregional cooperations, primarily along the internal Schengen borders. In the framework of the larger scale cross-border organisational structures (Euroregions), and/or besides these the smaller scale cross-border cooperations (micro-region to micro-region, micro-region to town, town to town, associations of towns and municipalities - quasi "miniature Euroregions") are gaining importance; also, the role of the gateway functions of the middle and big cities and the role of the other intermunicipal relations is strengthening. In the case of Hungary and the neighbours on the other side of the internal Schengen borders, the border regions and the cross-border cooperation may promote the strengthening of the connecting (bridging) role, the reorganisation of the past integrations, the "reunification" of the spatial units torn apart by the Treaty of Trianon - in the optimal case the birth of a new transnational macro-regional economic space in the Carpathian Basin. 